\title{
ANALISIS PENGARUH TINGKAT PENGETAHUAN MASYARAKAT TERHADAP TINDAKAN SWAMEDIKASI DIARE AKUT DI KECAMATAN PONTIANAK TIMUR
}

\author{
Robiyanto $^{1}$, Monika Rosmimi ${ }^{2}$, Eka Kartika Untari ${ }^{3}$ \\ ${ }^{1,2,3}$ Program Studi Farmasi Fakultas Kedokteran Universitas Tanjungpura \\ Jalan Prof. Dr. H. Hadari Nawawi Pontianak 78124 \\ 1e-mail: robiyant@gmail.com
}

\begin{abstract}
Abstrak
Penelitian bertujuan untuk: (1) mengetahui ada tidaknya pengaruh karakteristik meliputi usia, jenis kelamin, pekerjaan, dan pendidikan terhadap tindakan swamedikasi diare akut; dan (2) Menganalisis pengaruh tingkat pengetahuan terhadap tindakan swamedikasi diare akut pada masyarakat yang tinggal di Kecamatan Pontianak Timur. Penelitian tergolong penelitian observasional dengan rancangan penelitian potong lintang. Pengambilan sampel dengan metode quota sampling dengan jumlah subjek penelitian sebanyak 60 responden. Teknik pengumpulan data dengan penyebaran kuesioner. Uji statistik data menggunakan chi square test. Kesimpulan dari penelitian menunjukkan bahwa: (1) Usia dan pendidikan memiliki pengaruh terhadap pengetahuan swamedikasi; dan (2) Tingkat pengetahuan responden ternyata berpengaruh terhadap tindakan swamedikasi diare akut.
\end{abstract}

Kata Kunci: diare akut, swamedikasi, tingkat pengetahuan.

\begin{abstract}
The purpose of research are to: (1) Determine the influence of characteristics e.g. age, gender, occupation, and level of education toward Eastern Pontianak community who practice self-medication for acute diarrhea; and (2) Analyze the relationship between the knowledge level of community toward self-medication attempt. This research is an observational research with cross-sectional study design. Samples are obtained using quota sampling method with 60 respondents as subject of the research. Data collection is done by distributing questionnaire. Statistical data was processed using Chi Square test. The conclusion of research are (1) Education level and age affect the knowledge in self-medication; and (2) The level of knowledge of the respondent affects the attempt in acute diarrhea selfmedication $(P<0.05)$.
\end{abstract}

Keywords: acute diarrhea, self-medication attempt, level of knowledge.

\section{PENDAHULUAN}

Swamedikasi berarti mengobati segala keluhan pada diri sendiri dengan obat-obat yang sederhana yang dibeli bebas di apotek atau toko obat atas inisiatif sendiri tanpa nasehat dokter atau tenaga kesehatan terlebih dahulu (Tjay \& Raharja, 2010). Swamedikasi menjadi alternatif yang diambil masyarakat untuk meningkatkan keterjangkauan pengobatan. Pada pelaksanaannya swamedikasi dapat menjadi sumber terjadinya kesalahan pengobatan (medication error) karena 
keterbatasan pengetahuan masyarakat akan obat dan penggunaannya (DepKes RI, 2010).

Praktik swamedikasi umumnya dilakukan oleh masyarakat untuk mengatasi penyakit-penyakit yang tidak tergolong parah, seperti sakit kepala, demam, batuk, pilek, diare, dan lain-lain. Diare merupakan suatu penyakit yang ditandai dengan meningkatnya frekuensi buang air besar lebih dari tiga kali sehari disertai adanya perubahan bentuk dan konsistensi tinja penderita (Harianto, 2004). Diare akut yaitu diare yang berlangsung kurang dari 2 minggu (Noerasid, dkk., 1988). Berdasarkan data Riset Kesehatan Dasar (Riskesdas) tahun 2007, prevalensi diare klinis yaitu $9 \%$.

Menurut penelitian Kamila, dkk. (2012) di Kalimantan Barat kasus kesakitan dan kematian penyakit diare cukup tinggi, yaitu nomor 3 setelah demam berdarah dan tuberkulosis (TB) paru. Data Dinas Kesehatan Kota Pontianak menunjukkan angka kesakitan diare sekitar 22,2\% penduduk dengan jumlah kasus yang ditemukan sebesar 8374 kasus di enam Kecamatan yang berada di wilayah Kota Pontianak. Jumlah kasus yang tinggi ditemukan di wilayah Pontianak Timur sebesar 1430 kasus (Kamila, dkk., 2012).

Berdasarkan uraian tersebut, maka penelitian bertujuan untuk mengetahui hubungan atau pengaruh karakteristik sosiodemografi meliputi faktor usia, jenis kelamin, jenis pekerjaan, dan tingkat pendidikan terhadap tindakan swamedikasi diare akut masyarakat di Kecamatan Pontianak Timur serta menganalisis pengaruh tingkat pengetahuan terhadap tindakan swamedikasi diare akut pada masyarakat di Kecamatan Pontianak Timur.

\section{METODE}

Penelitian merupakan penelitian observasional dengan rancangan penelitian cross sectional yang bersifat deksriptif. Teknik pengumpulan data dilakukan dengan menyebarkan kuesioner pertanyaan pada masyarakat di Kecamatan Pontianak Timur yang pernah melakukan swamedikasi diare akut. Sampel dalam penelitian adalah seluruh masyarakat yang memenuhi kriteria inklusi dan tidak memenuhi kriteria eksklusi. Sampel diambil dengan menggunakan metode quota 
sampling hingga jumlah sampel yang diperlukan terpenuhi. Analisis statistik chi square digunakan untuk mengetahui pengaruh tingkat pengetahuan terhadap tindakan masyarakat dalam swamedikasi diare akut.

\section{HASIL DAN PEMBAHASAN}

Data demografi responden sangat penting untuk diketahui sebagai gambaran latar belakang dan distribusi tingkat sosial masyarakat yang ada di daerah Kecamatan Pontianak Timur yang dapat mempengaruhi tingkat pengetahuan dan tindakan swamedikasi diare akut. Pada penelitian digunakan responden sebanyak 60 orang yang sesuai dengan kriteria inklusi. Berdasarkan hasil kuesioner diperoleh data demografi responden sebagai berikut.

Tabel 1 Distribusi Frekuensi Karakteristik Seluruh Subjek Penelitian

\begin{tabular}{clcc}
\hline No & \multicolumn{1}{c}{$\begin{array}{c}\text { Karakteristik } \\
\text { Sosiodemografi }\end{array}$} & $\begin{array}{c}\text { Jumlah } \\
(\mathbf{N = 6 0 )}\end{array}$ & $\begin{array}{c}\text { Persentase } \\
(\mathbf{\%})\end{array}$ \\
\hline 1 & Usia (tahun) & & \\
& Remaja (12-25) & 16 & 26,7 \\
& Dewasa (26-45) & 44 & 73,3 \\
\hline 2 & Jenis Kelamin & & \\
& Perempuan & 49 & 81,7 \\
& Laki-laki & 11 & 18,3 \\
\hline 3 & Pekerjaan & 46 & 76,7 \\
& Tidak Bekerja & 14 & 23,3 \\
& Bekerja & & \\
\hline 4 & Tingkat Pendidikan & 48 & 80 \\
& Pendidikan Rendah-Sedang & 12 & 20 \\
& Pendidikan Tinggi & & \\
\hline
\end{tabular}

Terlihat dari Tabel 1 bahwa masyarakat yang melakukan swamedikasi diare akut umumnya berusia 26 - 45 tahun yang termasuk golongan dewasa. Kelompok usia dewasa merupakan kelompok usia produktif, apabila kesehatannya terganggu orang dewasa akan mengambil keputusan untuk melakukan pengobatan sendiri. Semakin bertambah usia akan semakin berkembang daya tangkap dan pola pikir, sehingga pengetahuan tentang swamedikasi yang diperolehnya semakin baik.

Berdasarkan Tabel 1 juga diperoleh informasi bahwa responden perempuan lebih banyak yang melakukan swamedikasi diare akut dan lebih sering 
mencari informasi dari tetangga atau orang terdekat mengenai swamedikasi diare akut dikarenakan perempuan lebih peduli terhadap kesehatan diri dan keluarganya. Hasil penelitian Hebeeb dan Gearhart (1993) menyatakan jenis kelamin berhubungan dengan perilaku pengobatan sendiri. Responden perempuan lebih banyak melakukan pengobatan sendiri karena perempuan cenderung lebih berhati-hati dalam melakukan pengobatan dibandingkan laki-laki dan akan lebih memilih untuk berkonsultasi terlebih dahulu ke dokter terkait dengan obat yang diigunakannya (Hebeeb dan Gearhart, 1993).

Hasil penelitian berdasarkan karakteristik pekerjaan menunjukkan bahwa pada masyarakat dengan status tidak bekerja ditemukan paling banyak, termasuk kategori didalamnya yaitu ibu tumah tangga. Hal tersebut dapat terjadi karena sebagian besar perempuan adalah ibu rumah tangga dan apabila salah satu anggota keluarga menderita sakit, maka ibu rumah tangga tersebutlah yang sering melakukan swamedikasi terutama swamedikasi diare akut sehingga mendorong keingintahuan untuk mencari informasi yang benar terkait swamedikasi diare akut tersebut.

Berdasarkan karakteristik tingkat pendidikan, dapat disimpulkan bahwa pada masyarakat di Kecamatan Pontianak Timur paling banyak memiliki latar belakang pendidikan rendah (SD, SMP, dan SMA). Perbedaan tingkat pendidikan dapat menyebabkan perbedaan penggunaan pelayanan kesehatan oleh individu yang berkaitan dengan pengetahuan kesehatan, nilai, dan sikap (Notoatmodjo, 2005).

Tabel 2. Analisis Hubungan antara Usia dengan Pengetahuan Swamedikasi Diare Akut

\begin{tabular}{|c|c|c|c|c|c|c|c|}
\hline \multirow{2}{*}{$\begin{array}{c}\text { Usia } \\
\text { (Tahun) }\end{array}$} & \multicolumn{4}{|c|}{ Pengetahuan } & \multirow[b]{2}{*}{$\begin{array}{c}\text { Nilai } \\
\mathbf{p}\end{array}$} & \multirow[b]{2}{*}{ OR } & \multirow[b]{2}{*}{$95 \% \mathrm{CI}$} \\
\hline & $\begin{array}{l}\text { Tidak } \\
\text { Baik }\end{array}$ & $\%$ & Baik & $\%$ & & & \\
\hline $\begin{array}{l}\text { Remaja } \\
(12-25)\end{array}$ & 10 & 66,7 & 4 & 8,9 & 0,000 & 20,500 & $4,461-90,546$ \\
\hline $\begin{array}{l}\text { Dewasa } \\
(26-45)\end{array}$ & 5 & 33,3 & 41 & 91,1 & ref & Ref & ref \\
\hline
\end{tabular}


Tabel 2 menunjukkan bahwa pengetahuan tentang swamedikasi diare akut tidak baik pada usia remaja (12-25 tahun) sebanyak 10 orang serta 4 orang dengan pengetahuan yang baik, pada usia dewasa (26-45 tahun) pengetahuan tentang swamedikasi diare akut tidak baik sebanyak 5 orang dan 41 orang dengan pengetahuan baik. Hasil menunjukkan bahwa usia remaja (12-25 tahun) memiliki pengetahuan yang kurang baik dibandingkan dengan usia dewasa (26-45 tahun). Hasil uji dengan chi square, didapatkan bahwa syarat-syarat untuk memenuhi uji chi square terpenuhi karena nilai $\mathrm{p}=0,000<0,05$. Dapat disimpulkan bahwa terdapat hubungan bermakna antara usia dengan pengetahuan swamedikasi diare akut. Nilai $\mathrm{OR}=20,500>1$ menunjukkan bahwa pada responden usia remaja (1225 tahun) 20,5 kali beresiko dibandingkan responden usia dewasa (26-45 tahun) untuk memiliki pengetahuan yang tidak baik tentang swamedikasi diare akut.

Tabel 3 Analisis Hubungan antara Tingkat Pendidikan dengan Pengetahuan Swamedikasi Diare Akut

\begin{tabular}{ccccccccc}
\hline \multirow{2}{*}{$\begin{array}{c}\text { Tingkat } \\
\text { Pendidikan }\end{array}$} & \multicolumn{3}{c}{ Pengetahuan } & Nilai p & OR & 95\% CI \\
\cline { 2 - 6 } & $\begin{array}{c}\text { Tidak } \\
\text { baik }\end{array}$ & $\%$ & Baik & $\%$ & & & \\
\hline Pendidikan dasar & 15 & 100 & 33 & 73,3 & 0,025 & 0,668 & $0,568-$ \\
& & & & & & & 0,832 \\
Pendidikan tinggi & 0 & 0 & 12 & 26,7 & Ref & ref & ref \\
\hline
\end{tabular}

Berdasarkan Tabel 3 dapat dikatakan bahwa pengetahuan tidak baik (15 orang) dan baik (33 orang) pada responden yang mengenyam pendidikan dasar (SD, SMP, dan SMA). Seluruh responden dengan pendidikan tinggi memiliki pengetahuan yang baik (12 orang) dan tidak baik (0 orang). Hasil chi square menunjukkan nilai $p$ value $=0,025<0,05$ menunjukkan terdapat perbedaan bermakna antara tingkat pendidikan masyarakat dengan pengetahuan mengenai swamedikasi diare akut. Hal tersebut berarti, semakin tinggi tingkat pendidikan masyarakat, maka semakin baik pula pengetahuan masyarakat tentang swamedikasi diare akut. 
Tabel 4 Analisis Pengaruh Pengetahuan terhadap Tindakan Swamedikasi Diare Akut

\begin{tabular}{|c|c|c|c|c|c|}
\hline \multirow[b]{2}{*}{ Pengetahuan } & \multicolumn{4}{|c|}{ Tindakan } & Nilai p \\
\hline & $\begin{array}{l}\text { Tidak } \\
\text { Tepat }\end{array}$ & $\%$ & Tepat & $\%$ & \multirow[t]{3}{*}{0,000} \\
\hline Tidak baik & 15 & 100 & 0 & 0 & \\
\hline Baik & 0 & 0 & 45 & 100 & \\
\hline
\end{tabular}

Tabel 4 menampilkan angka signifikansi yang didapatkan dari uji chi square yaitu $p$ value $=0,000<0,05$. Hal tersebut menunjukkan bahwa secara statistik terdapat hubungan antara pengetahuan terhadap tindakan swamedikasi diare akut pada masyarakat di Kecamatan Pontianak Timur. Jika pengetahuan masyarakat baik, maka tindakan swamedikasi yang dilakukan masyarakat juga akan benar, dan sebaliknya.

Tabel 5 Permasalahan pada Kesesuaian Pengenalan Diare

\begin{tabular}{|c|c|c|c|}
\hline \multirow{2}{*}{ No } & \multirow{2}{*}{$\begin{array}{l}\text { Pertanyaan Mengenai Pengetahuan } \\
\text { Swamedikasi Diare Akut }\end{array}$} & \multicolumn{2}{|c|}{ Jumlah } \\
\hline & & S-SS & STS-TS \\
\hline 1 & $\begin{array}{l}\text { Diare adalah penyakit yang ditandai dengan } \\
\text { buang air besar dengan bentuk tinja lembek } \\
\text { bahkan cair lebih dari } 3 \text { kali dalam sehari. }\end{array}$ & 47 & 13 \\
\hline 2 & $\begin{array}{l}\text { Semua gangguan saluran pencernaan pasti } \\
\text { menimbulkan diare. }\end{array}$ & 37 & 23 \\
\hline 3 & Diare selalu disebabkan oleh kuman. & 42 & 18 \\
\hline 4 & $\begin{array}{l}\text { Diare dapat diikuti dengan gejala sakit perut, } \\
\text { mual, dan demam. }\end{array}$ & 39 & 21 \\
\hline 5 & $\begin{array}{l}\text { Diare dapat menyebabkan gangguan } \\
\text { keseimbangan air dalam tubuh, misalnya kurang } \\
\text { minum air yang dapat menyebabkan kematian. }\end{array}$ & 33 & 27 \\
\hline 6 & $\begin{array}{l}\text { Pengobatan yang paling penting untuk } \\
\text { menangani penyakit diare adalah dengan oralit. }\end{array}$ & 44 & 16 \\
\hline 7 & $\begin{array}{l}\text { Untuk menyembuhkan diare, antibiotik harus } \\
\text { selalu digunakan. }\end{array}$ & 37 & 23 \\
\hline 8 & $\begin{array}{l}\text { Oralit adalah larutan yang berisi campuran gula, } \\
\text { garam, kalium, dan natrium yang digunakan } \\
\text { untuk mengganti cairan tubuh yang hilang akibat } \\
\text { diare. }\end{array}$ & 43 & 17 \\
\hline 9 & $\begin{array}{l}\text { Beberapa contoh obat penghenti diare adalah } \\
\text { oralit, obat untuk mengurangi buang air besar, } \\
\text { obat untuk memadatkan tinja, dan obat untuk } \\
\text { meningkatkan penyerapan cairan dan elektrolit. }\end{array}$ & 35 & 25 \\
\hline
\end{tabular}

Keterangan: SS = Sangat Setuju; S = Setuju; TS = Tidak Setuju; STS = Sangat Tidak Setuju 
Berdasarkan Tabel 5 diketahui bahwa pertanyaan nomor 1 pada kuesioner tentang definisi diare dari 60 responden menjawab setuju-sangat setuju sebanyak 47 orang dan sangat tidak setuju-tidak setuju sebanyak 13 orang. Markum (1999) mengatakan bahwa diare adalah buang air besar dengan frekuensi tiga kali atau lebih perhari disertai perubahan feses menjadi cair dengan atau tanpa lendir atau darah. Permasalahan terjadi pada pertanyaan nomor 2 dan 3 tentang penyebab diare, pada pertanyaan kedua menunjukkan hasil yaitu responden menjawab setuju-sangat setuju sebanyak 37 orang dan sangat tidak setuju-tidak setuju sebanyak 23 orang. Pada pertanyaan nomor tiga diperoleh hasil setuju-sangat setuju sebanyak 42 orang dan sangat tidak setuju-tidak setuju sebanyak 18 orang. Penyebab diare akut dapat berupa infeksi ataupun noninfeksi. Penyebab infeksi dapat berupa bakteri, virus, ataupun parasit (Markum, 1999). Penyebab noninfeksi dapat berupa obat-obatan, alergi makanan, penyakit primer gastrointestinal seperti, inflammatory bowel disease, atau berbagai penyakit sistemik seperti, tirotoksikosis dan sindrom karsinoid (Crittenden, et al., 2005). Pada pertanyaan nomor 4 tentang gejala sebanyak 39 orang menjawab setuju-sangat setuju dan 21 orang menjawab sangat tidak setuju-tidak setuju. Gejala klinis berupa mulas sampai nyeri seperti kolik, mual, muntah, demam, tenesmus, serta gejala dan tanda dehidrasi (Farthing, et al., 2013).

Pertanyaan nomor 5, 6, dan 8 adalah mengenai pengetahuan tentang penggunaan oralit, diperoleh hasil yaitu setuju-sangat setuju sebanyak 33, 44, dan 37 orang dan sangat tidak setuju-tidak setuju sebanyak 27, 16, dan 17 orang. Penatalaksanaan pasien diare akut dimulai dengan terapi simtomatik, seperti rehidrasi dan penyesuaian diet. Terapi terpenting pada diare akut adalah rehidrasi, lebih disenangi melalui rute oral dengan larutan yang mengandung air, garam, dan gula (Farthing, et al., 2013).

Terapi rehidrasi oral (oral rehydration therapy/ORT) merupakan pemberian cairan melalui mulut untuk mencegah atau mengoreksi dehidrasi akibat diare. Pada dasarnya ORT terdiri dari 2 bagian, yaitu rehidrasi, ditujukan untuk mengganti air dan elektrolit yang hilang dan terapi cairan rumat (bersama nutrisi 
yang sesuai). Larutan rehidrasi oral (oral rehydration solution/ORS) adalah cairan yang khusus dibuat untuk terapi rehidrasi oral. Pada banyak kasus diare usus kecil fungsi absorpsi glukosa usus melalui cotransport natrium glukosa masih baik, yang terganggu hanya fungsi sekresi dari usus halus, sehingga air masih bisa diserap oleh usus kecil bila glukosa dan garam juga tersedia untuk membantu tranpor air dari lumen usus (Zein, 2004) .

World Health Organization (WHO) telah mengembangkan ORS hipotonik untuk digunakan secara global karena ORS berosmolaritas rendah (konsentrasi natrium dan glukosanya lebih sedikit) lebih efektif dalam mengurangi muntah, keluarnya feses, serta kebutuhan infus intravena dibandingkan dengan ORS standar (Thielman dan Guerrant, 2004).

Penelitian Harianto (2004) menyatakan bahwa penggunaan oralit merupakan cara efektif untuk mengatasi diare karena oralit dapat mencegah terjadinya dehidrasi dengan menggantikan elektrolit dan cairan tubuh yang hilang. Penelitian Agtini (2011) juga menambahkan bahwa pencegahan dehidrasi dapat dilakukan mulai dari rumah tangga dengan memberikan oralit untuk mengganti cairan tubuh yang hilang. Siswidiasari, dkk. (2014) juga mendukung bahwa resiko dehidrasi akibat diare dapat diatasi dengan terapi yang pertama yaitu dengan pemberian CRO (Cairan Rehidrasi Oral) berupa oralit.

Timbul permasalahan pada pertanyaan nomor 7 yaitu tentang penggunaan antibiotik dalam swamedikasi diare akut. Hasil dari 60 responden menunjukkan bahwa responden setuju-sangat setuju sebanyak 37 orang dan sangat tidak setujutidak setuju 23 sebanyak orang. Terapi antibiotik tidak diperlukan pada sebagian besar kasus diare akut karena penyakit biasanya sembuh sendiri (self-limited) (Thielman dan Guerrant, 2004). Pemberian antibiotik secara empiris jarang diindikasikan pada diare akut infeksi, karena 40\% kasus diare infeksi sembuh kurang dari 3 hari tanpa pemberian antibiotik (Farthing, et al., 2013).

Pertanyaan nomor 9 adalah tentang obat-obatan lain yang dapat digunakan dalam mengobati diare selain oralit, diperoleh hasil respoden menjawab setujusangat setuju sebanyak 35 orang dan 25 orang menjawab sangat tidak setuju-tidak setuju. Beberapa contoh obat penghenti diare selain oralit adalah obat untuk 
mengurangi buang air besar (anti motilitas) seperti difenoxilat, loperamid, paregoric, opium tinctureife, dan difenoxin. Obat untuk memadatkan tinja (adsorben) yaitu kaolin-pektin, polycarbophy, dan attapulgit. Obat untuk meningkatkan penyerapan cairan dan elektrolit (anti sekretori) yaitu bismuth subsalisilat, enzime (laktase), dan bakteri pengganti (Lactobacillus ascorphilus, Lactobacillus burgaricus).

Tabel 6 Permasalahan pada Kesesuaian Tindakan Mengatasi Diare

\begin{tabular}{|c|c|c|c|}
\hline \multirow[b]{2}{*}{ No } & \multirow{2}{*}{$\begin{array}{c}\text { Pertanyaan Mengenai Tindakan Swamedikasi } \\
\text { Diare Akut }\end{array}$} & \multicolumn{2}{|c|}{ Jumlah } \\
\hline & & S-SS & STS-TS \\
\hline 1 & $\begin{array}{l}\text { Ketika saya menderita diare lebih dari } 3 \text { hari, } \\
\text { namun kondisinya belum parah, maka belum } \\
\text { perlu berobat ke dokter. }\end{array}$ & 27 & 33 \\
\hline 2 & $\begin{array}{l}\text { Menurut saya obat yang paling penting untuk } \\
\text { mengatasi penyakit diare adalah oralit. }\end{array}$ & 42 & 18 \\
\hline 3 & $\begin{array}{l}\text { Menurut saya orang yang sakit diare sebaiknya } \\
\text { jangan diberi minuman atau asupan cairan terlalu } \\
\text { banyak agar tinjanya menjadi padat. }\end{array}$ & 14 & 46 \\
\hline 4 & $\begin{array}{l}\text { Ketika saya menderita diare tanpa lendir, darah } \\
\text { atau berwarna putih seperti air cucian beras, saya } \\
\text { selalu berobat ke dokter. }\end{array}$ & 35 & 25 \\
\hline 5 & $\begin{array}{l}\text { Ketika saya menderita diare tanpa lendir, darah } \\
\text { atau berwarna putih seperti air cucian beras, } \\
\text { maka saya akan membeli obat sendiri ke apotek } \\
\text { atau warung, dan setelah } 3 \text { hari tidak membaik } \\
\text { saya baru pergi ke dokter. }\end{array}$ & 34 & 26 \\
\hline 6 & $\begin{array}{l}\text { Ketika saya atau anggota keluarga saya } \\
\text { menderita diare, hal pertama yang saya lakukan } \\
\text { adalah membeli oralit. }\end{array}$ & 56 & 4 \\
\hline 7 & $\begin{array}{l}\text { Saya selalu memperhatikan kegunaan obat dan } \\
\text { aturan pakai yang tertera pada kemasan obat. }\end{array}$ & 43 & 17 \\
\hline
\end{tabular}

Keterangan: SS = Sangat Setuju; S = Setuju; TS = Tidak Setuju; STS: Sangat Tidak Setuju

Pertanyaan nomor 1 adalah tentang tindakan yang dilakukan jika menderita diare. Hasil pada Tabel 6 menunjukkan bahwa 27 responden setuju-sangat setuju dan 33 responden sangat tidak setuju-tidak setuju. Seharusnya jika diare sudah berlangsung lebih dari 3 hari, harus diperiksa ke dokter walaupun kondisinya belum parah karena khaatir terjadi dehidrasi jika dibiarkan. Ketika swamedikasi yang dilakukan tidak berhasil, artinya penyakit tersebut harus ditangani oleh 
dokter untuk mendapatkan penanganan yang serius. Sedangkan pertanyaan 2, 3, dan 6 membahas tentang penggunaan oralit.

Hasil jawaban pertanyaan nomor 7 menunjukkan sebanyak 43 orang responden setuju-sangat setuju dan 17 orang sangat tidak setuju-tidak setuju ketika harus memperhatikan kegunaan obat dan aturan pakai yang tertera pada kemasan obat. Nasution dan Lubis (1993) menyatakan bahwa ketika menggunakan obat-obatan tanpa resep yang perlu diperhatikan adalah kondisi obat, tanggal kadaluarsa, indikasi, dan kontraindikasi, efek samping, dosis obat, cara penyimpanan obat, dan interaksi obat dengan obat lain. Sartono (1993) juga mengatakan informasi yang penting diketahui tentang obat adalah indikasi, kontra indikasi, dosis pemakaian, dan efek samping agar penggunaan obat misalnya untuk mengatasi diare menjadi rasional.

\section{SIMPULAN}

Berdasarkan hasil dan pembahasan, maka dapat disimpulkan bahwa: (1) Usia dan pendidikan memiliki pengaruh terhadap swamedikasi; dan (2) Keberhasilan tindakan swamedikasi diare akut pada masyarakat di Kecamatan Pontianak Timur dipengaruhi oleh tingkat pengetahuan masyarakat sendiri.

\section{DAFTAR PUSTAKA}

Agtini, D. 2011. Morbiditas Dan Mortalitas Diare Pada Balita Di Indonesia. Jakarta: Kementerian Kesehatan Republik Indonesia.

Crittenden, R. et al. 2005. Probiotic research in Australia, New Zealand and The Asia Pacific region. Current Pharmaceutical Design. 11: 37-53.

Departemen Kesehatan Republik Indonesia. 2010. Profil Kesehatan Indonesia. Jakarta: Departemen Kesehatan Republik Indonesia.

Farthing, M., Salam, M. A., Lindberg, G., Dite, P., Khalif, I., \& Salazar-Lindo, E. 2013. Acute Diarrhea In Adults And Children: A Global Perspective. World Gastroenterology Organisation Global Guidelines. J Clin Gastroenterol. 47(1): $12-20$.

Harianto. 2004. Penyuluhan Penggunaan Oralit Untuk Menanggulangi Diare Di Masyarakat. Jakarta: Departemen Farmasi UI. 
Hebeeb, G. E. \& Gearhart, J. G. 1993. Common Patient Symptoms: Patterns Of Self-Treatment And Prevention. Journal of Miss State Med Association, 34(6): 81-179.

Kamila, L., Suhartono, \& Wendah, N. 2012. Hubungan Praktek Personal Hygiene Ibu dan Kondisi Sanitasi Lingkungan Rumah dengan Kejadian Diare pada Balita Di Puskesmas Kampong dalam Kecamatan Pontianak Timur. Jurnal Kesehatan Indonesia, 2(2): 138-143.

Markum, A. H. 1999. Buku Ajar Ilmu Kesehatan Anak Jilid 1. Jakarta: Balai Penerbit FKUI.

Nasution, H. \& Lubi,s Y. 1993. Pengantar Farmakologi Edisi II. Medan: PT Pustaka Widyatarana.

Noerasid, dkk. 1988. Gastroenteritis (Diare) Akut edisi Gastroenterology Anak Praktis. Jakarta: Balai Penerbit FK UI.

Notoatmodjo. 2005. Promosi Kesehatan: Teori Dan Aplikasi. Jakarta: Rieneka Cipta.

Sartono. 1993. Obat Wajib Apotek. Jakarta: Gramedia.

Siswidiasari, A., Astuti, K. W., \& Yowani S. C. 2014. Profil Terapi Obat pada Pasien Rawat Inap dengan Diare Akut pada Anak di Rumah Sakit Umum Negara. Jurnal Kimia, 8(2): 183-190.

Thielman, N. M. \& Guerrant, R. L. 2004. Acute Infectious Diarrhea. $N$ Eng $J$ Med, 350: 38-47.

Tjay, T. H. \& Raharja, K. 2010. Obat-Obatan Sederhana untuk Gangguan SehariHari. Jakarta: Gramedia.

Zein, U. 2004. Diare akut infeksius pada dewasa. e-USU Repository [Internet]. Available from: http://repository .usu.ac.id/bitstream/123456789/3388/1/ penydalam-umar4.pdf. 